Original research article

\title{
NTPDase, 5'-nucleotidase and adenosine deaminase activities and purine levels in serum of sickle cell anemia patients
}

\author{
Lívia G. Castilhos ${ }^{\mathrm{a}}$, Stephen A. Adefegha ${ }^{\mathrm{b}, \mathrm{c}}$, Pedro H. Doleski ${ }^{\mathrm{b}}$, Tatiana M.D. Bertoldo ${ }^{\mathrm{a}}$, \\ Cesar Eduardo J. Moritz ${ }^{\mathrm{d}}$, Emerson A. Casali ${ }^{\mathrm{e}}$, Daniela B.R. Leal ${ }^{\mathrm{a}, \mathrm{b}, *}$
}

${ }^{a}$ Federal University of Santa Maria, Post-Graduate Program in Pharmaceutical Sciences, Santa Maria, RS, Brazil

${ }^{\mathrm{b}}$ Federal University of Santa Maria, Post-Graduate Program in Toxicological Biochemistry, Santa Maria, RS, Brazil

${ }^{\mathrm{c}}$ Federal University of Technology, Department of Biochemistry, Akure, Nigeria

d Federal University of Rio Grande do Sul, Post-Graduate Program in Science of Human Movement, Porto Alegre, RS, Brazil

e Federal University of Rio Grande do sul, Departament of Morphological Sciences, Porto Alegre, RS, Brazil

\section{A R T I C L E I N F O}

Article history:

Received 31 May 2016

Received in revised form 25 November 2017

Accepted 12 December 2017

Available online 26 December 2017

\section{Keywords:}

NTPDase

5'-nucleotidase

Adenosine deaminase

Serum

Sickle cell anemia

\section{A B S T R A C T}

Sickle cell anemia (SCA) is a hereditary disorder that is characterized by tendency of hemoglobin molecules within the erythrocytes to polymerize under hypoxia conditions, deform the red cells, and promote vaso-occlusion and endothelial damage. This disease may be associated with the extracellular release of nucleotides, particularly ATP, ADP and adenosine into the circulation. The aim of this study was to investigate the possible changes in adenine nucleotides and nucleoside metabolizing enzymes as well as their levels in serum of SCA patients. NTPDase, 5'-nucleotidase and adenosine deaminase activities were evaluated in serum obtained from blood samples of 15 SCA treated patients and 15 healthy subjects (control group). The results revealed that there were significant $(P<0.001)$ elevations in NTPDase, 5 -nucleotidase and ADA activities in serum of SCA treated patients when compared to the control group. Furthermore, no significant $(P>0.05)$ alteration was observed in ATP, ADP and adenosine levels of both SCA treated and control groups. However, inosine level was significantly $(P<0.05)$ decreased and hypoxanthine level was higher in SCA treated patients $(P<0.001)$ when compared to the control group. The results suggest the involvement of purinergic signaling enzymes in the maintenance of the levels of extracellular nucleotides and nucleosides, thus preventing some pathophysiological conditions associated with SCA.

(C) 2017 Faculty of Health and Social Sciences, University of South Bohemia in Ceske Budejovice. Published by Elsevier Sp. z o.o. All rights reserved.

\section{Introduction}

Sickle cell anemia (SCA) is a hereditary disorder of hemoglobin caused by a single missense mutation in the human $\beta$-globin gene leading to an amino acid substitution (Glu $\rightarrow$ Val) in the sixth position of the $\beta$-globin chain. The polymerization results into $\mathrm{HbS}$ abnormal hemoglobin under hypoxic conditions, induces a mechanical distortion of red blood cells and indicates a key event in the complex pathophysiology of SCA (Hebbel, 2011). It is a chronic hemolytic anemia characterized by ongoing vaso occlusion; persistent endothelial damage and progressive organ damage (Fasano et al., 2015). Sickle cell disease may be associated with the extracellular release of nucleotides and nucleoside, particularly

\footnotetext{
* Author for correspondence: Universidade Federal de Santa Maria, Microbiologia e Parasitologia, Avenida Roraima, 1000, Brazil.

E-mail address: dbitencourtrosaleal@gmail.com (D.B.R. Leal).
}

adenosine triphosphate (ATP), adenosine diphosphate (ADP) and adenosine into the circulation (Jackson et al., 1996). ATP is as an important extracellular messenger and a major metabolic currency that is expended in cellular activities (Di Virgilio et al., 2009). In healthy tissues, ATP is almost exclusively localized intracellularly (Di Virgilio et al., 2009) but in pathological processes is released from damaged cells and the concentration in the extracellular space rises rapidly (Cekic and Linden, 2016).

ATP can be hydrolyzed by ectonucleotidases that are situated on the surface of cells, in soluble forms in the interstitial medium or within body fluids (Zimmermann et al., 2012). These circulating soluble nucleotidases play significant role in controlling the availability of ATP, ADP, AMP and adenosine in the extracellular environment within physiological limits (Agteresch et al., 1999; Zimmermann et al., 2012). An enzymatic cascade coordinates these dual functions of removing one signal in the form of ATP and generating another in form of adenosine (Agteresch et al., 1999). 
The measurement of the rate of ATP enzymatic hydrolysis in human blood may serve as a promising diagnostic tool for cellular damage in various pathophysiological conditions (Yegutkin, 1997).

Extracellular adenine nucleotides are hydrolyzed by series of enzymes; nucleoside triphosphate diphosphohydrolase family (NTPDases), nucleotide phosphate/phosphodiesterase family, alkaline phosphatases and 5'-nucleotidase. NTPDases hydrolyze ATP and ADP while 5'-nucleotidase hydrolyzes AMP to adenosine (Zimmermann, 2000). Adenosine deaminase is another important enzyme that is released to the extracellular space by monocytes, macrophages and dendritic cells. It is responsible for the deamination of adenosine to inosine (Zavialov et al., 2010).

Previous studies have demonstrated the presence of soluble NTPDases, 5'-nucleotidase and adenosine deaminase in rat blood serum as well as in human blood (Doleski et al., 2016; Oses et al., 2004; Yegutkin, 1997; Yegutkin et al., 2007). In addition, our earlier reports have shown that these membrane-bound enzymes may mediate and modulate purinergic system in lymphocytes and platelets of sickle cell anemia patients (Castilhos et al., 2015, 2016). However, there is dearth of information on the activities and levels of the soluble NTPDases in SCA. Thus, we speculated that soluble NTPDases, 5'-nucleotidase and adenosine deaminase may also participate in the regulation of adenine nucleotides in serum of SCA patients. To accomplish this, we investigated the possible changes in adenine nucleotides and nucleoside metabolizing enzymes as well as the levels of nucleotides and nucleosides in serum of SCA patients.

\section{Materials and methods}

\section{Chemicals}

The substrates ATP, ADP, AMP, adenosine, as well as trizma base, coomassie brilliant blue $G$ and bovine serum albumin were obtained from Sigma Chemical Co (St. Louis, MO, USA) and $\mathrm{K}_{2} \mathrm{HPO}_{4}$ was purchased from Merck (Darmstadt, Germany). All the other chemicals used in this experiment were of the highest purity.

\section{Patients and samples}

The samples consisted of $15 \mathrm{HbSS}$ patients all in steady state (SCA group) with a mean male age of 33 (range: $31-38$ years old) and mean female age of 26 (range: 18-51 years old). The control group was consisted of 15 healthy subjects with a mean male age of 27 (range: 20-36 years old) and mean female age of 23 (range: 18-35 years old). The diagnosis of SCA was based on International Statistical Classification of Diseases and Related Health Problems (ICD 10) (D 57.0/57.1) (World Health Organization, 2015). All the patients were currently receiving medications, such as folic acid and hydroxyurea. These patients were using for treatment a dose of $5 \mathrm{mg}$ per day and $35 \mathrm{mg} / \mathrm{kg} /$ day of folic acid and hydroxyurea (more than 2 months of treatment), respectively. The subjects gave written consent to participate in this study and the Human Ethics Committee of the Health Science Center from the Federal University of Santa Maria approved the project under the registration number; 512.074. Subjects with altered blood pressure, alcoholism, cigarette smoking or diagnostic of diabetes mellitus, autoimmune disease and immunodeficiency were excluded in this study. SCA patients who received blood transfusion at least two months earlier were also excluded. In this study, 15 SCA patients and 15 healthy control individuals were chosen in line with a priori analysis using the G-power program according to the method reported by Mayr et al. (2007).

\section{Isolation of blood serum fraction}

The blood samples were collected in tubes without anticoagulant and clots were formed. After the clot formation, the tubes were placed in a centrifuge at $5000 \times g$ for $5 \mathrm{~min}$ at room temperature. The resultant serum samples were aliquoted in microtubes, placed in the refrigerator and subsequently used for the assessment of enzyme activity and quantification of purine levels.

\section{Protein determination}

Protein concentration was determined by the Coomassie Blue method (Bradford, 1976), using bovine serum albumin as standard.

\section{Determination of NTPDase and 5'-nucleotidase activities}

ATP and ADP hydrolyses were determined with slight modifications (Oses et al., 2004). The reaction mixture containing ADP or ATP as substrate (final concentration of $3.0 \mathrm{mM}$ ), $112.5 \mathrm{mM}$ Tris- $\mathrm{HCl}, \mathrm{pH} 8.0$, was incubated with approximately $1.0 \mathrm{mg}$ of serum protein at $37{ }^{\circ} \mathrm{C}$ for $40 \mathrm{~min}$ in a final volume of $0.2 \mathrm{ml}$. The reaction was stopped by the addition of $0.2 \mathrm{ml}$ of $10 \%$ TCA. The samples were chilled on ice and the amount of inorganic phosphate (Pi) liberated was measured (Chan et al., 1986). In order to correct the non-enzymatic hydrolysis, appropriate controls were carried out by adding the serum after the reaction was stopped with TCA. All samples were centrifuged at 5,000 $\times g$ for $5 \mathrm{~min}$ to eliminate precipitated protein and the supernatant was used for the colorimetric assay. AMP hydrolysis was assessed using a similar method described above for ATP and ADP hydrolysis. The reaction mixture, containing $3.0 \mathrm{mM}$ AMP as substrate in $100 \mathrm{mM}$ Tris- $\mathrm{HCl}, \mathrm{pH} 7.5$, was incubated with $0.5-1.0 \mathrm{mg}$ serum protein at $37^{\circ} \mathrm{C}$ in a final volume of $200 \mu \mathrm{l}$. All other procedures were the same as described above for ATP and ADP hydrolysis. All samples were assayed in triplicate. Enzyme activities were expressed as nanomoles of Pi released per min per mg of protein.

\section{Determination of ADA activity}

ADA activity in serum was measured by spectrophotometric method (Giusti and Gakis, 1971). Twenty-five microliters of serum were used. The reaction was started by addition of $475 \mu \mathrm{l}$ of $21 \mathrm{mM}$ adenosine as substrate and incubated for $1 \mathrm{~h}$ at $37^{\circ} \mathrm{C}$. The reaction was stopped by adding $1.5 \mathrm{ml}$ of $106 / 0.16 \mathrm{mM}$ phenol-nitroprusside to the reaction mixture, which was immediately mixed with $1.5 \mathrm{ml}$ of 125/11 mM alkaline hypochlorite (sodium hypochlorite). The ammonia released reacts with alkaline-hypochlorite and phenol in the presence of a catalyst - sodium nitroprusside - to produce indophenol (a blue color). The concentration of ammonia is directly proportional to the indophenol and the absorbance was read at $650 \mathrm{~nm}$. Seventy-five micromolar of ammonium sulfate was used as ammonium standard. The measurement was performed in duplicate. The values of ADA activity in serum were expressed as $U / \mathrm{mg}$ of protein.

In vitro effects of drugs used in the treatment of SCD patients on determination of nucleotide hydrolysis

The in vitro effects of Folic acid and Hydroxyurea on NTPDase, $5^{\prime}$-nucleotidase and ADA activities were evaluated. Serum from health subjects were incubated with Folic acid and Hydroxyurea in the medium reaction as previously described. The concentrations of this drugs used in vitro were based on the mean plasma values of the medications (Almeida et al., 2012). 
Analysis of purine levels by high-pressure liquid chromatography (HPLC)

Purine levels and metabolic residues of ATP hydrolysis of serum samples were analyzed by HPLC. The denaturation of proteins was performed using $0.6 \mathrm{~mol} / \mathrm{l}$ perchloric acid. All samples were then centrifuged $\left(14,000 \times \mathrm{g}\right.$ for $10 \mathrm{~min}$ at $\left.4{ }^{\circ} \mathrm{C}\right)$, supernatants were neutralized with $4.0 \mathrm{~N} \mathrm{KOH}$ and a second centrifugation $(14,000 \times g$ for $30 \mathrm{~min}$ at $4{ }^{\circ} \mathrm{C}$ ) was done. After second centrifugation, the supernatants were collected and centrifuged again $(14,000 \times \mathrm{g}$ for $30 \mathrm{~min}$ at $\left.4{ }^{\circ} \mathrm{C}\right) .20 \mu \mathrm{l}$ of aliquots were analyzed in a reversed-phase HPLC (Shimadzu, Japan) using a $\mathrm{C}_{18}$ column (Ultra C18, $25 \mathrm{~cm} \times 4.6 \mathrm{~mm} \times 5 \mu \mathrm{m}$, Restek - USA). The elution was carried out by applying a linear gradient from $100 \%$ solvent A (60 mM $\mathrm{KH}_{2} \mathrm{PO}_{4}$ and $5 \mathrm{mM}$ of tetrabutylammonium phosphate, $\mathrm{pH} 6.0$ ) to $100 \%$ of solvent B (solvent A plus $30 \%$ methanol) over a $30 \mathrm{~min}$ period (flow rate at $1.4 \mathrm{ml} / \mathrm{min}$ ) (Voelter et al., 1980). The amounts of purines were measured by absorption at $254 \mathrm{~nm}$. The retention time of standards was used as parameter for identification and quantification. Purines concentrations were expressed as nmol of compound per $\mathrm{ml}$ of serum.

\section{Statistical analysis}

The comparisons were performed using the Student's $t$-test for independent samples. The results are expressed as mean \pm standard error of the mean (SEM). Differences were considered significant at $P<0.05$. A priori analysis was used to determine the necessary sample size $\mathrm{N}$ based on Mayr et al. (2007) report.

\section{Results}

\section{General characteristics of the patients}

Fifteen SCA patients consisting of five males with mean age of 33 (range: 31-38 years old) and ten females with mean age of 26 (range: 18-51 years old). These patients were placed on treatment with doses of $5 \mathrm{mg}$ per day and $35 \mathrm{mg} / \mathrm{kg} /$ day of folic acid and hydroxyurea respectively. Fifteen healthy individuals with mean age for males as 29 (range: 19-37 years old) and mean age for females as 23 (range: 18-35 years old) formed the control group.

\section{Determination of nucleotide hydrolysis}

The results of the NTPDase activity in serum of patients with SCA group and control groups are shown in Fig. 1. The hydrolysis of ATP by serum NTPDase activity was significantly $(P<0.001)$ higher in SCA patients $(4.1 \mathrm{nmol}$ of $\mathrm{Pi} / \mathrm{min} / \mathrm{mg}$ of protein; $\mathrm{SEM}=0.5$; $n=15$ ) when compared to the control group ( $1.4 \mathrm{nmol}$ of $\mathrm{Pi} / \mathrm{min} /$ mg of protein; SEM $=0.5 ; n=15$ ) (Fig. $1 \mathrm{~A}$ ). Furthermore, the ADP hydrolysis by serum NTPDase activity was significantly increased in the SCA group $(3.4 \mathrm{nmol} \mathrm{Pi} / \mathrm{min} / \mathrm{mg} ; \mathrm{SEM}=0.5 ; n=15 ; P<0.001$ ) when compared to control group $(1.3 \mathrm{nmol}$ of $\mathrm{Pi} / \mathrm{min} / \mathrm{mg}$ of protein; $\mathrm{SEM}=0.5 ; n=15$ ) (Fig. 1B). In addition, the hydrolysis of AMP by $5^{\prime}$-nucleotidase activity in serum of patients with SCA and control group is shown in Fig. 2. There was a significant elevation in AMP hydrolysis in SCA group $(0.55 \mathrm{nmol}$ of $\mathrm{Pi} / \mathrm{min} / \mathrm{mg}$ of protein; $\mathrm{SEM}=0.12 ; n=15 ; P<0.001)$ when comparing to control group $(0.37 \mathrm{nmol}$ of $\mathrm{Pi} / \mathrm{min} / \mathrm{mg}$ of protein; $\mathrm{SEM}=0.09 ; n=15)$.

\section{ADA activity in serum}

The results obtained for serum ADA activity are presented in Fig. 3. Adenosine deaminase activity was higher in SCA group $(0.6 \mathrm{U} / \mathrm{mg}$ protein; $\mathrm{SEM}=0.2 ; n=15 ; P<0.001)$ than control group (0.3 $\mathrm{U} / \mathrm{mg}$ protein; $\mathrm{SEM}=0.1 ; n=15)$.
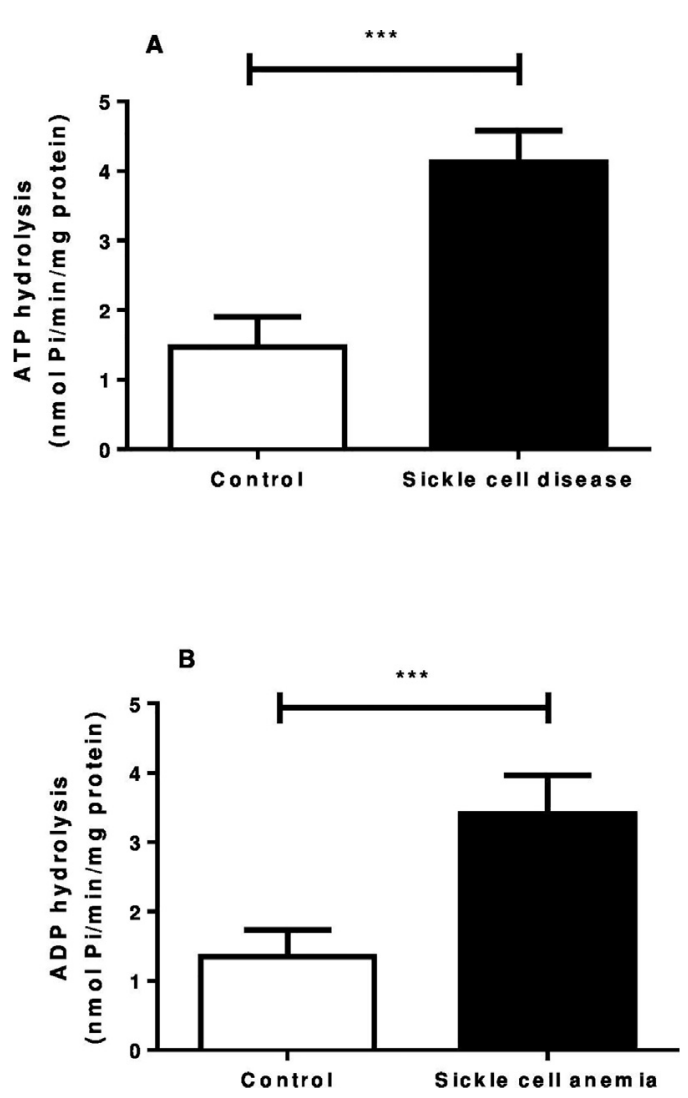

Fig. 1. ATP (A) and ADP (B) hydrolysis by NTPDase in serum of SCA and control patients. Enzyme specific activities were reported as nmol of Pi released $/ \mathrm{min} / \mathrm{mg}$ of protein. Variables were expressed as mean \pm standard error of the mean (SEM). Bars represent mean \pm S.E.M. (“***”) indicates a significant $(P<0.001)$ difference between the SCA patients $(n=15)$ and control $(n=15)$. Student's $t$-test for independent samples was used for all the analyses.

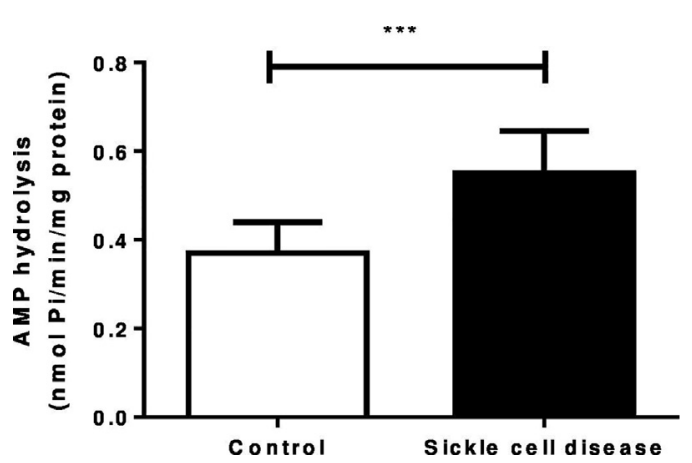

Fig. 2. AMP hydrolysis by $5^{\prime}$-nucleotidase in serum of control and patients with SCA. Enzyme activity was reported as nmol of Pi released $/ \mathrm{min} / \mathrm{mg}$ of protein. Variables were expressed as mean \pm standard error of the mean (SEM). Bars represent mean \pm S.E.M. (“****) indicates a significant $P<0.001$, with $n=15$ (controls) and $n=15$ (SCA) (Student's $t$-test for independent samples.).

In vitro effects of drugs used in the treatment of SCD patients on determination of nucleotide hydrolysis

Results obtained for the in vitro effects of NTPDase, 5'nucleotidase and ADA activities showed that there were no alterations in the activities of NTPDase, 5'-nucleotidase and ADA when folic acid and hydroxyurea drugs were used in the reaction medium $(P>0.05, n=15)$ (data not shown). 


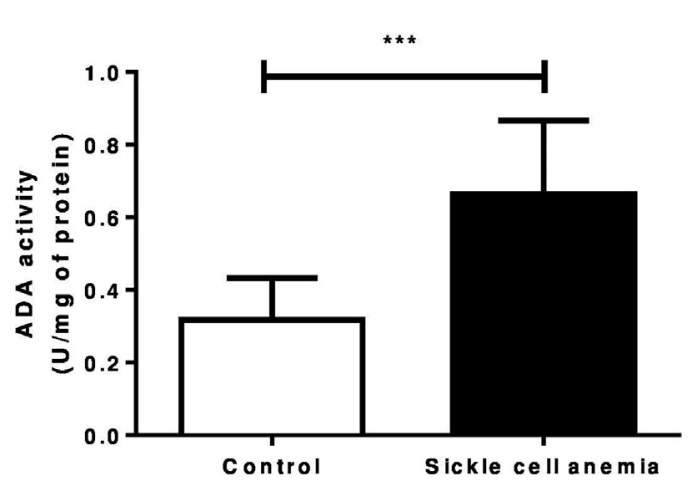

Fig. 3. Adenosine deamination in serum of control and patients with SCA. Enzyme activities were reported as $\mathrm{U} / \mathrm{mg}$ of protein. Variables were expressed as mean \pm standard error of the mean (SEM). Bars represent mean \pm S.E.M. (“***”) indicates a significant $P<0.001$, with $n=15$ (controls) and $n=15$ (SCA) (Student's $t$-test for independent samples).

\section{Purine levels}

Purine levels in serum were measured by HPLC and are shown in Fig. 4. Levels of ATP, ADP, AMP and adenosine were not significantly altered in SCA group when compared to control group. However, the level of inosine was significantly decreased in SCA group $(0.4 \mathrm{nmol} / \mathrm{ml} ; \mathrm{SEM}=0.1 ; n=15 ; P<0.05)$ when compared to control group $(0.9 \mathrm{nmol} / \mathrm{ml} ; \mathrm{SEM}=0.2 ; n=15)$. Conversely, there was a significant $(P<0.001)$ increase in the level of hypoxanthine in SCA group ( $25.2 \mathrm{nmol} / \mathrm{ml}$; SEM = 1.5; $n=15)$ when compared to the control group $(9.5 \mathrm{nmol} / \mathrm{ml}$; SEM $=0.5 ; n=15)$.

\section{Discussion}

Pathologic conditions such as inflammation and ischemia occur in sickle cell disease and are directly associated with the extracellular release of nucleotides, particularly of ATP and ADP (Jackson et al., 1996; Sun and Xia, 2013). Previous studies have shown that elevated ATP levels may occur due to nucleotide release from the red blood cells in response to low oxygen tension and hemoglobin deoxygenation (Ellsworth, 2004; Ellsworth et al., 1995). In addition, its levels and effects could be attenuated by soluble NTPDase activity. To our best knowledge, this is the first report where the relationship between adenine nucleotides hydrolyzing enzymes and its levels in serum of SCA patients was studied. Certain amounts of soluble NTPDase activity are constitutively circulated in human bloodstream (Yegutkin et al., 2007). In this study, the observed elevations in ATPase and ADPase activities in serum of SCA patients may indicate the pathophysiological conditions associated with SCA and the attempt to maintain the ATP and ADP levels at physiological concentration (Ralevic and Burnstock, 1998; Yegutkin et al., 2006). High concentrations of ATP and ADP in the extracellular medium activate the pro-inflammatory purinergic $\mathrm{P} 2 \mathrm{X} 7$ receptors and contribute to tissue damage (Di Virgilio, 1995), platelets induction aggregation and thrombus formation, respectively (Puri, 1999).

These findings corroborate with previous results obtained from our research group where increased E-NTPDase activity for ATP and ADP hydrolyses were also observed in lymphocytes (Castilhos et al., 2015) and platelets of SCA patients (Castilhos et al., 2016). Soluble NTPDase enzyme may thus be fundamentally importance as a diagnostic marker in SCA. In this study, the non-significant change in ATP and ADP levels between SCA patients and healthy individuals may suggest a compensatory mechanism initiated by high ATPase and ADPase activity in serum in order to maintain normal physiological concentrations of ATP and ADP in SCA patients. Earlier studies have revealed that physiological concentrations of extracellular nucleotides are usually in nanomolar range under normal conditions (Yegutkin et al., 2006) and the presence of high ATP concentrations are considered cytotoxic (Ralevic and Burnstock, 1998).

Oses et al. (2004) reported that soluble NTPDase with 5 '-nucleotidase from rat blood serum may act by lowering ATP, ADP and AMP, as well as increasing the concentration of adenosine, which is a potent vasodilator. Besides the increased ATPase and ADPase activities observed in this study, the AMPase activity was also significantly higher in SCA patients when compared to healthy subjects. This result agrees with the study of Mohamed et al. (1993), where an increase in $5^{\prime}$-nucleotidase activity in serum of patients with sickle cell anemia was reported. The increased AMPase activity observed in SCA patients may be a compensatory mechanism that could be directly related to the amount of AMP nucleotide produced by high ATPase and ADPase activity and typified by the extracellular normal nanomolar range of AMP measured by HPLC in this study. Cellular release of ATP/ADP may result in feed-forward inhibition of 5'-nucleotidase and delay of extracellular adenosine formation until their extracellular levels have been reduced to low micromolar levels by nucleotidases (James and Richardson, 1993). The 5'-nucleotidase catalyzes the formation of adenosine from extracellular AMP and activation of P1 adenosine receptors (Zimmermann, 1996). Adenosine is an endogenous regulatory metabolite and inhibitor of platelet aggregation (Galen et al., 1992). Adenosine released from different cells or produced through the activity of cell surface ectoenzymes, exerts its effects through the binding of four different G-proteincoupled adenosine receptors. In platelets, binding of $A_{2}$ subtypes $\left(A_{2 A}\right.$ or $\left.A_{2 B}\right)$ leads to consequent elevation of intracellular cyclic adenosine monophosphate, an inhibitor of platelet activation (Johnston-Cox and Ravid, 2011).

ADA catalyzes the deamination of adenosine and deoxyadenosine into their respective inosine nucleoside (Cristalli et al., 2001). This conversion is an initial step in a series of reactions responsible for lymphocyte proliferation and differentiation. Moreover, ADA is considered an indicator of cellular immunity and fundamental for the differentiation of lymphocytes (Blake and Berman, 1982). In this study, the increased ADA activity observed in serum of SCA patients may lead to a decrease in extracellular adenosine levels and increase in extracellular inosine production. Increased adenosine levels play a functional role in promoting sickling, hemolysis and damage to multiple tissues in sickle cell disease through the induction of 2,3-DPG in erythrocytes (Zhang et al., 2011). Production of 2,3-DPG occurs only in RBCs and decreases the oxygen binding affinity of hemoglobin (Sasaki and Chiba, 1983).

ADA may be a marker of inflammation during hypoxia and its expression is increased in SCA (Eltzschig et al., 2006). The elevated levels of adenosine in SCA patients observed in this study may be attributed to the increased AMPase activity and could compensate for the increased ADA activity observed in SCA. Our result follows similar trend with previous investigation in our laboratory where increased E-ADA activity was reported in lymphocytes and platelets of SCA patients (Castilhos et al., 2015, 2016), reinforcing the involvement and alterations of this membrane-bound and soluble NTPDase as well as ADA activities in the pathophysiology of SCA. This is also in agreement with the work of Silva-Pinto et al. (2014) that observed HU-treated patients displayed increased ADA activity, compared with untreated, indicating a novel mechanism of action of HU mediated by the reduction of adenosine levels and its effects on pathophysiological processes in SCA.

Adenosine level was observed to be regulated to the normal level in the serum of SCA patients. However, the results obtained for the HPLC analysis of other purine levels revealed that inosine was significantly decreased while hypoxanthine level was elevated in SCA. The reason for the alterations of these important purines 

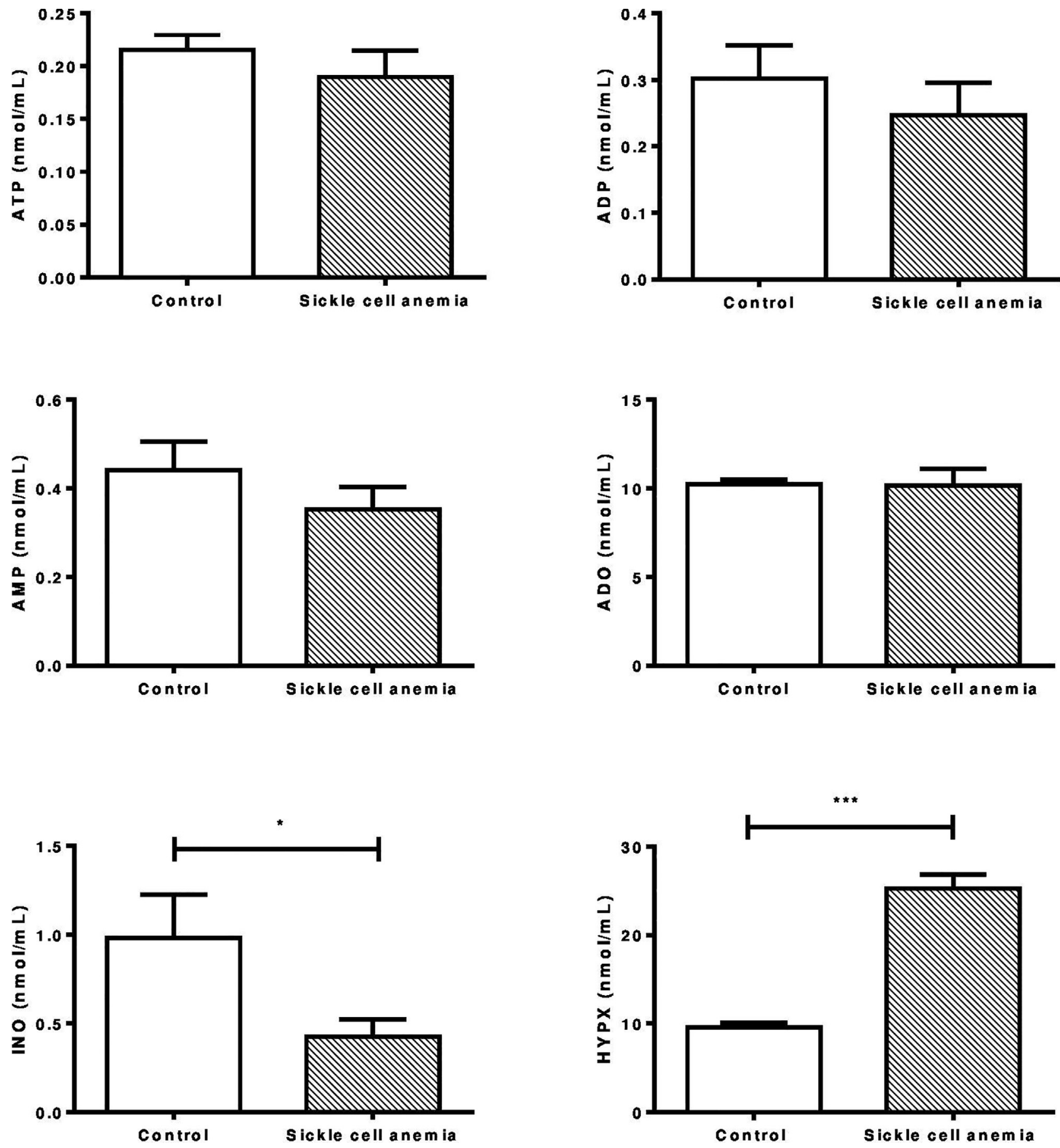

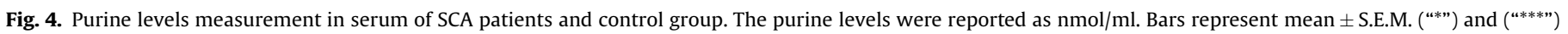
indicate a significant $P<0.05$ and $P<0.001$ respectively, with $n=15$ (controls) and $n=15$ (SCA) (Student's $t$-test for independent samples).

(inosine and hypoxanthine) levels in SCA may not be categorically stated. The whole blood in humans including the red blood cell (RBC) contains purine nucleoside phosphorylase (PNP); an enzyme that converts inosine to hypoxanthine (Farthing et al., 2015). Although, the PNP activity has not been investigated in this study, we speculate that the increased PNP activity may probably have facilitated the rapid breakdown of inosine to hypoxanthine and the availability of hypoxanthine could play a pivotal role in reperfusion injury associated with SCA (Rao et al., 1990).

In addition to the increased NTPDase, 5'-nucleotidase and ADA activities in SCA patients, we performed an in vitro study to verify if treatment with folic acid and hydroxyurea could modify these enzyme activities in SCA patients. The preliminary results do not show that these drugs modify these activities. This may be adjudged that these activities are solely from the enzymes present on serum of SCA patients. The hypothesis of in vitro effects of the two drugs analyzed was to check whether the drugs could modify the activities of the enzymes in normal healthy individual. Hence, results from our study show that these drugs do not modify the activities of NTPDase, $5^{\prime}$-nucleotidase and ADA in vitro in healthy individuals. Although, we may not be able to categorically state the effect of the drugs on the activities of NTPDase, $5^{\prime}$-nucleotidase and ADA activities in SCA in vitro, however, we observed that there was a significant change in NTPDase, $5^{\prime}$-nucleotidase and ADA activities 
in vivo in SCA patients in comparison to the normal healthy subjects.

\section{Conclusion}

The results obtained in the present study revealed that the alterations in soluble NTPDase, $5^{\prime}$-nucleotidase, and ADA activities in sickle cell disease, raising the possibility that purinergic signaling is involved and altered in serum of SCA patients. Also, the involvement of purinergic enzymes may be necessary in the regulation of physiological concentrations of nucleotides and nucleosides in serum of SCA patients. This is a preliminary study and the role of the components of purinergic signaling in the pathophysiology of sickle cell disease has been reported. However, further studies are ongoing to assess the heterogeneity of the clinical manifestation and response to $\mathrm{HU}$ and folic acid treatment. In addition, we aim to explore the possible heterogeneity between individual SCA patients as well as the polymorphisms of the NTPDase, 5'-nucleotidase and ADA genes and their receptors in subsequent studies.

\section{Conflict of interests}

The authors declare that they have no conflict of interests.

\section{Acknowledgements}

We sincerely thank the sickle cell anemia patients who accepted to participate in the study, the Serviço de HematoOncologia do Hospital Universitário de Santa Maria and Projeto Pilão - Presença Negra no Campo, Projeto "Educação e Saúde na Doença Falciforme" do Centro de Ciências da Saúde-Departamento de Saúde da Comunidade - UFSM for supplying some materials used for the experiment. This study was supported by the Conselho Nacional de Desenvolvimento Científico e Tecnológico (CNPq), Fundação de Amparo à Pesquisa do Rio Grande do Sul (FAPERGS), and Fundação Coordenação de Aperfeiçoamento de Pessoal de Nível Superior (CAPES), Brazil.

\section{References}

Agteresch, H.J., Dagnelie, P.C., Van den Berg, J.W., Wilson, J.H., 1999. Adenosine triphosphate: established and potential clinical applications. Drugs 58 (2), 211 232.

Almeida, C.C., Brentani, H.P., Forlenza, O.V., Diniz, B.S., 2012. Serum folic acid is reduced in patients with Alzheimer's disease. Rev. Psiquiatr. Clin. 39 (3), 90-93.

Blake, J., Berman, P., 1982. The use of adenosine deamination assays in the diagnosis of tuberculosis. S. Afr. Med. J. 62 (1), 19-21.

Bradford, M.M., 1976. A rapid and sensitive method for the quantification of microgram quantities of protein utilizing the principle of protein-bye binding Anal. Biochem. 72, 248-254.

Castilhos, L.G., Doleski, P.H., Bertoldo, T.M., Passos, D.F., Bertoncheli, C.M., Rezer, J.F. et al., 2015. Sickle cell anemia induces changes in peripheral lymphocytes ENTPDase/E-ADA activities and cytokines secretion in patients under treatment. Biomed. Pharmacother. 73, 102-108.

Castilhos, L.G., Doleski, P.H., Adefegha, S.A., Becker, L.V., Ruchel, J.B., Leal, D.B., 2016 Altered E-NTPDase/E-ADA activities and CD39 expression in platelets of sickle cell anemia patients. Biomed. Pharmacother. 79, 241-246.

Cekic, C., Linden, J., 2016. Purinergic regulation of the immune system. Nat. Rev. Immunol. 16 (3), 177-192.

Chan, K.M., Delfert, D., Junger, K.D., 1986. A direct colorimetric assay for Ca2+ stimulated ATPase activity. Anal. Biochem. 157 (2), 375-380.

Cristalli, G., Costanzi, S., Lambertucci, C., Lupidi, G., Vittori, S., Volpini, R., et al., 2001. Adenosine deaminase: functional implications and different classes of inhibitors. Med. Res. Rev. 21 (2), 105-128.

Di Virgilio, F., 1995. The P2Z purinoreceptor: an intriguing role in immunity inflammation and cell death. Immunol. Today 16 (11), 524-528.

Di Virgilio, F., Boeynaems, J.M., Robson, S.C., 2009. Extracellular nucleotides as negative modulators of immunity. Curr. Opin. Pharmacol. 9 (4), 507-513.
Doleski, P.H., Mendes, R.E., Leal, D.B.R., Bottari, N.B., Piva, M.M., Da Silva, E.S., et al., 2016. Seric and hepatic NTPDase and $5^{\prime}$ nucleotidase activities of rats experimentally infected by Fasciola hepatica. Parasitology 143 (5), 551-556.

Ellsworth, M.L., Forrester, T., Ellis, C.G., Dietrich, H.H., 1995. The erythrocyte as a regulator of vascular tone. Am. J. Physiol. 269 (6), H2155-H2161.

Ellsworth, M.L., 2004. Red blood cell-derived ATP as a regulator of skeletal muscle perfusion. Med. Sci. Sports Exerc. 36 (1), 35-41.

Eltzschig, H.K., Faigle, M., Knapp, S., Karhausen, J., Ibla, J., Rosenberger, P., et al., 2006. Endothelial catabolism of extracellular adenosine during hypoxia: the role of surface adenosine deaminase and CD26. Blood 108 (5), 1602-1610.

Farthing, D.E., Farthing, C.A., Xi, L., 2015. Inosine and hypoxanthine as novel biomarkers for cardiac ischemia: from bench to point-of-care. Exp. Biol. Med. (Maywood) 240 (6), 821-831.

Fasano, R.M., Meier, E.R., Hulbert, M.L., 2015. Cerebral vasculopathy in children with sickle cell anemia. Blood Cells Mol. Dis. 54 (1), 17-25.

Galen, P.J., Stiles, G.L., Michaels, G., Jacobson, K.A., 1992. Adenosine A1 and A2 receptors: structure-function relationships. Med. Res. Rev. 12 (5), 423-471.

Giusti, G., Gakis, C., 1971. Temperature conversion factors, activation energy, relative substrate specificity and optimum $\mathrm{pH}$ of adenosine deaminase from human serum and tissues. Enzyme 12417-12425.

Hebbel, R.P., 2011. Reconstructing sickle cell disease: a data-based analysis of the hyperhemolysis paradigm for pulmonary hypertension from the perspective of evidence-based medicine. Am. J. Hematol. 86 (2), 123-154.

Jackson, E.K., Mi, Z., Koehler, M.T., Carcillo Jr., J.A., Herzer, W.A., 1996. Injured erythrocytes release adenosine deaminase into the circulation. J. Pharmacol. Exp. Ther. 279 (3), 1250-1260.

James, S., Richardson, P.J., 1993. Production of adenosine from extracellular ATP at the striatal cholinergic synapse. J. Neurochem. 60 (1), 219-227.

Johnston-Cox, H.A., Ravid, K., 2011. Adenosine and blood platelets. Purin. Signal. 7 (3), 357-365.

Mayr, S., Erdfelder, E., Buchner, A., Faul, F., 2007. A short tutorial of GPower. Tutor. Quant. Methods Psychol. 3 (2), 51-59.

Mohamed, A.O., Jansson, A., Ronquist, G., 1993. Increased activity of 5'nucleotidase in serum of patients with sickle cell anaemia. Scand. J. Clin. Lab. Invest. 53 (7), 701-704.

Oses, J.P., Cardoso, C.M., Germano, R.A., Kirst, I.B., Rücker, B., Fürstenau, C.R., et al., 2004. Soluble NTPDase: an additional system of nucleotide hydrolysis in rat blood serum. Life Sci. 74 (26), 3275-3284.

Puri, R.N., 1999. ADP-induced platelet aggregation and inhibition of adenylyl cyclase activity stimulated by prostaglandins: signal transduction mechanisms. Biochem. Pharmacol. 57 (8), 851-859.

Ralevic, V., Burnstock, G., 1998. Receptors for purines and pyrimidines. Pharmacol. Rev. 50 (3), 413-492.

Rao, P.N., Walsh, T.R., Makowka, L., Rubin, R.S., Weber, T., Snyder, J.T., et al., 1990. Purine nucleoside phosphorylase: a new marker for free oxygen radical injury to the endothelial cell. Hepatology 11 (2), 193-198.

Sasaki, R., Chiba, H., 1983. Functions and metabolism of 2,3-bisphosphoglycerate in erythroid cells. Tanpakushitsu Kakusan Koso (Protein, Nucleic acid, Enzyme) 28 (8), 957-973.

Silva-Pinto, A.C., Dias-Carlos, C., Saldanha-Araujo, F., Ferreira, F.I., Palma, P.V., Araujo, A.G., et al., 2014. Hydroxycarbamide modulates components involved in the regulation of adenosine levels in blood cells from sickle-cell anemia patients. Ann. Hematol. 93 (9), 1457-1465.

Sun, K., Xia, Y., 2013. New insights into sickle cell disease: a disease of hypoxia. Curr. Opin. Hematol. 20 (3), 215-221.

Voelter, W., Zech, K., Arnold, P., Ludwig, G., 1980. Determination of selected pyrimidines, purines and their metabolites in serum and urine by reverse-phase ion-pair chromatography. J. Chromatogr. 199, 345-354.

World Health Organization (2015). International Statistical Classification of Diseases and Related Health Problems (ICD 10); 2015. [online] [cit. 2015-10-02]. Available from: http://www.who.int/classifications/icd/en/.

Yegutkin, G.G., 1997. Kinetic analysis of enzymatic hydrolysis of ATP in human and rat blood serum. Biochem. Biokh. 62 (6), 619-622.

Yegutkin, G.G., Mikhailov, A., Samburski, S.S., Jalkanen, S., 2006. The detection of micromolar pericellular ATP pool on lymphocyte surface by using lymphoid ecto-adenylate kinase as intrinsic ATP sensor. Mol. Biol. Cell 17 (8), 3378-3385.

Yegutkin, G.G., Samburski, S.S., Mortensen, S.P., Jalkanen, S., González-Alonso, 2007. Intravascular ADP and soluble nucleotidases contribute to acute prothrombotic state during vigorous exercise in humans. J. Physiol. 579 (Pt. 2), 553-564.

Zavialov, A.V., Gracia, E., Glaichenhaus, N., Franco, R., Zavialov, A.V., Lauvau, G., 2010. Human adenosine deaminase 2 induces differentiation of monocytes into macrophages and stimulates proliferation of $\mathrm{T}$ helper cells and macrophages. J. Leukoc. Biol. 88 (2), 279-290.

Zhang, Y., Dai, Y., Wen, J., 2011. Detrimental effects of adenosine signalling in sickle cell disease. Nat. Med. 17 (1), 79-86.

Zimmermann, H., 1996. Extracellular purine metabolism. Drug Dev. Res. 39 (3-4), $337-352$.

Zimmermann, H., 2000. Extracellular metabolism of ATP and other nucleotides. Naunyn Schmiedeberg's Arch. Pharmacol. 362 (4-5), 299-309.

Zimmermann, H., Zebisch, M., Strater, N., 2012. Cellular function and molecular structure of ecto-nucleotidases. Purin. Signal. 8 (3), 437-502. 